\title{
LEGAL ASPECTS OF WATER POLLUTION IN INDIA: A REVIEW ON STATUTORY FRAMEWORKS
}

\author{
Aboud S. Jumbe* \& N. Nandini**
}

\begin{abstract}
Water is cradle of life. To profect this precious resource, one needs a stringent enforcement system meant for its conservation, sanitation and supply. Environmental laws are meant to set standards for what people and institutions must do to control or prevent environmental pollution including water. Affer enactment it becomes the job of the central and state governments to make sure that those who are subject to these environmental protection laws know what they must do to comply. In this case, we have designated central and state institutions called the Central and State Pollution Control Boards respectively. Their primary role is the enforcement of the Environmental Protection Act (EPA) and its constituent statutory frameworks dating back to the Post Stockholm environmental laws such as the Water (Prevention and Control of Pollution) Act of 1974. This paper provides an insight into the evolution and development of the legal aspects of water pollution and its environment-related laws in India. It gives an assessment of these environment-related lows in a context of Pre-Stockholm and Post-
\end{abstract}

PhD Scholar Department of Environmental Science, Bangalore University, Jnanabharathi Campus; Bangalore 560056; Tel: +918022961365; Email: aboud.jumbe@gmail.com

** Reader and Chairperson, Deparment of Environmental Science, Bangalore University, Jnanabharathi Campus, Bangalore 560056, Tel: +9180 22961365, Email: Nondini.sai@rediffmail.com 
Stockholm statutory frameworks. The structural arrangements and functioning of the pollution control boards and the persistent challenges that they face in enforcing the laws of the land aimed at environmental protection are vital in understanding environmental management af policy and action levels. This is where citizen participation is vital.

\section{Introduction}

The Indian constitution recognizes the basic fundamental right of its citizens; the right to a clean and healthy environment. Article 21 of the constitution insists that no person shall be deprived of his/her life or personal liberty except according to the procedure laid down by law. By this article, the Supreme Court of India in the case of Subhas $v$ State of Bihar held that the Right to Environment is a fundamental right of every citizen in India as included in the right to live. The ruling states that the State has the responsibility to protect the environment as laid down under the Article $51-\mathrm{A}(\mathrm{g})$ of the Constitution of India. In other words, the Supreme Court underscores the fact that environmental rights indeed are human rights and they constitute everything from civil, political, economic, and social rights of people and communities in general. This link is inseparable.

Water is cradle of life. It is a basic human need and a finite life support system. To protect this precious resource, one needs a stringent enforcement system meant for its conservation, sanitation and supply. Environmental laws are meant to set standards for what people and institutions must do to control or prevent environmental pollution including water. After enactment it becomes the job of the central and state governments to make sure that those who are subject to these environmental protection laws know what they must do to comply. In this case, we have designated central and state institutions called the Central and State Pollution Control Boards respectively. Their primary role is the enforcement of the Environmental Protection Act (EPA) and its constituent statutory frameworks dating back to the Post Stockholm environmental laws such as the Water (Prevention and Control of Pollution) Act of 1974.

This paper provides basic insight into the evolution and development of the legal aspects of water pollution and its environment-related laws. The scope is to assess these environment-related laws in a context of two major phases of the history of environmental enforcement in our country; the localized Pre-Stockholm legal aspects based on the common law and the gradual shift towards the PostStockholm Environment-specific and globally accepted statutory frameworks. The second objective is to highlight the structural arrangemients and functioning of the pollution control boards and the persistent challenges that they face in 
enforcing the laws of the land aimed at absolute need for a citizen's power and invol ont in helping the communities conserve and protect their precious water resources by building up a culture of community based water quality monitoring and enforcement is another critical debate that needs equal attention.

\section{Pre-Stockholm Era: The Common Law Remedies: Public Nuisances; Damages \& Injunctions}

Common law is a body of customary law of England based on judicial decision. Today, that Common Law in India continues to be enforced under the Article 372 of the Constitution of India in so far as it is altered, repealed, or amended by a competent legislature or other authority.

\subsection{Public Nuisance \& Injunctions}

Perhaps the earliest known environmental case based on common law in India today is that involving J.C. Galstaun v Dunia Lal Seal in Calcutta. In 1905, Mr. Galstaun who had a garden house in one municipality in the suburbs of Calcutta, moved the court against the owner of the shellac factory that was situated nearby his home. In his complaint, the factory was discharging liquid effluents in a municipal drain passing in front of the plaintiff's house. This, he claimed, caused much inconvenience on him and therefore causing a health risk status. The court ruled in favour of the plaintiff and ordered the owner of the factory to pay $\mathrm{Mr}$ Galstaun Rs. 1000/- in damages.

This recorded landmark ruling was instrumental in showing just how as much the people of India of that time were long and fully exposed to the environmental awareness as we are today. This dispels the notion that India lacked any environmental awareness before the World Environment Conference of Stockholm, Sweden, in 1972. The above case also shows that the Common Law remedies for environmental pollution problems in India had been largely made available for people to fight environmental crimes at that time.

People then used to fight environmental crimes, and especially water pollution crimes under the Law of Torts. The Tort liabilities for environmental pollution were and still are made available under the context of Public Nuisance, negligence, and Strict Liability; and Damages \& Injunctions. Remedies found on Public Nuisance law include criminal prosecution for the offence causing public 
inconvenience; criminal proceeding before a magistrate for removing pubic nuisance; and civil action by advocate general or by two or more members of the public with permission of the court declaration, injunction, or both.

It is probable that cases at that time were largely fought in the context of environmental preservationism and desirable aesthetics quality. But people knew definitely well the health hazards posed on them by polluting industries that were exploiting all possible resources of water supply for their economic and industrial utilization regardless of health risks they posed on their own communities. It is also true that even though the provisions of the common law which had a bearing on the environment were hardly used in the past, the judiciary at that time did respond to the demands of people and society in general. For example, in 1926, the same remedy was used in Deshi Sugar Mill $\checkmark$ Tupsi Kahar. On the request of about a hundred people, the sub-divisional magistrate ordered that the two sugar mills in the locality should discontinue the release of dirty and toxic water to the river.

Another land mark case involving the use of common law remedies was in 1931 in today's Uttar Pradesh, when, in the case of Raghunandan v Emperor, the Allahabad High Court upheld the order of a magistrate forbidding a factory owner from operating his factory at night from 9.00 p.m to 5.00 a.m because it was both injurious to the physical discomfort of the community in terms of noise and water pollution.

The challenges towards the common law remedies for environmental problems started showing up at the height of an industrial India. For example, in 1958, the Madhya Pradesh High Court in Shaukat v Sheodayal attempted to limit the applications of the law of the Public Nuisance in dealing with pollution cases. The argument was for the industrial growth and development of society. Now the question of ethics had just erupted. What was ethical or unethical at this juncture was irrelevant at a time when India was striving towards human development and advancement of technology for the society.

In 1979, the Supreme Court of India decided to analyse again the parameters of the laws of public nuisance regarding environmental protection as explained in Govind Singh v Shanti. But the highest tone of judicial activism involving the common law remedies came about in the famous Ratlam Case in 1980. In this case called Municipal Council, Ratlam, $v$ Vardhichand the Supreme Court of India identified the responsibilities of local bodies towards protection of environment and developed the law of public nuisance in criminal procedure as a potent instrument for enforcement of their duties. 
After Stockholm, there developed a conflict of jurisdiction between the old Common law Remedies and the newly constituted Water Act of 1974. A question arose __ If there were new environmental statutes, wouldn't it be unacceptable for people to keep on coming to the courts using traditional gateways of environmental justice such as the common law? This proved extremely difficult to digest as the following two court case decisions reminded the weary society of the limits of the courts in the use of these remedies.

First, in Tata Tea $v$ State of Kerala (1984) the court accepted that and held that in so far as the case relates to prevention of water pollution, the provisions in Section 133 of Criminal Procedure Code was impliedly repealed by the Water (Prevention and Pollution Control Act) 1974. Again, the power vested in the Pollution Control Board by the Water and Air Acts of 1974 and 1981 respectively was the grounds in which the Madhya Pradesh High Court denied the magistrate jurisdiction under the same s $133 \mathrm{CrPC}$ in Abdulhamid $v$ Gwalior Rayon Silk Manufacturing $\mathrm{Co}$. In this court case, discharge of pollutants into the river had caused the death of children and animals. However, the magistrate abstained from taking action under the $S 133 \mathrm{CrPC}$ pointing to the remedies under the Water and Air Acts. On revision, the High Court endorsed the stand and said that the board should have been approached for sanction to prosecute the offenders.

However, in 1993, in M Krishna Panicker v Appukuttan Nair, the division of the bench of the Kerala High Court overruled the Single Bench decision in Tata Tea $\checkmark$ State of Kerala of 1984. In this very important decision that signalled the judicial acceptance of the use of the common laws after the establishment of Post-Stockholm environmental legislations such as the Water and Air Acts, the Court argued that the Water (Prevention and Pollution Control) Act, 1974 did not repeal the common law remedies.

\subsection{Damages}

In 1987, M.C. Mehta successfully used Damages remedy in M.C. Mehta v Union of India in a Shri Oleum Gas leak case. Mehta argued for the principle of "absolute liability" (Polluter Pays Principles) as laid down in an 1868 England Case known as Rylands $v$ Fletcher. Earlier the court held that the rule laid down in Rylands $v$ Fletcher was more than a century old and that it could no longer address the current problems fully. But Supreme Court ruled that when an industry is engaged in a hazardous or inherently dangerous activity e.g. toxic gases escape, the enterprise is strictly liable to all those who are affected by accident without any exception as laid down in Rylands $v$ Fletcher. 


\section{Post-Stockholm: Citizen Suits; Right of Information; and Public Interest Litigation}

\subsection{Citizen's Suits:}

Some people suggest that the beginnings of the Indian environmental laws were sown at the United Nations Conference on Environment held in Stockholm, Sweden in 1972. The conference came after wider realization that environmental crisis had reached global proportions and that countries around the world needed to establish a universal framework with which they could protect their global environment. The crisis had reached near global catastrophe and that what was needed was stringent regulations for environmental statutory laws to help the body of common laws which were already being outdone in the name of growth and development. So began the Water (Prevention and Control Pollution) Act, 1974 as the real foundation for the environmental protection. The Air (Prevention and Control of Pollution) Act of 1981 and later the Environment Protection Act, 1986, followed.

The real focus, as in any other enforcement issue, is the accessibility and transparency of the whole enforcement process as well. Section 1.9 of the Environment Protection Act, 1986 states that if any person violates any provision of the Act or any orders or directions made there under, such persons can be prosecuted in a criminal court. But this will only happen if the authority (in this case the Pollution Control Board) responsible for prosecuting the polluter fails to do so within 60 days of receiving the complaint, people can approach the criminal court and have that polluter appropriately punished under sections 15,16 , or 17 of the Act.

Until the coming of the Environmental Protections Act, 1986, prosecutions under the Indian environmental laws could only be done by the Government. Public interest groups or citizens had no statutory remedy against a polluter who discharged effluents beyond legally permissible limits other than those in common laws. But now, under the Section 19 of the EPA, a citizen could now use the law to prosecute any polluter/company BUT provided that a 60-Day notice was given of the intent to prosecute. Based on this provision the Air and Water Acts were amended to fall in line with the above EPA provision. Section 49 of the Water (Prevention and Control of Pollution) as amended in 1988 and Section 43 of the Air Act as amended in 1987 provided that new window of citizen's enforcement of environmental laws of India other than those of the common law. 
Evidently, the Bhopal Gas tragedy compelled the Government of India to begin thinking about citizen's empowerment in environmental enforcement issues. Eventually, in 1995, the Government of India issued a gazette notification empowering local communities with the Right of Information regarding hazardous activities surrounding their environment, predominantly from the industries. The rules set in the gazette were in accordance with Section 10 and section 11 of the EPA, 1986. It was suggested that the four-tier crisis group at the local, district, state and centrat levels comprising of village heads, local NGOs, Social Workers, Media persons, health practitioners, and local administrators would be empowered by the central Government to "..enter, inspect, and collect suspected industrial samples from their neighbourhood factory units, and therefore respond to all public enquiries on that subject in that particular area. As per the draft notification, the Central Government was going to constitute a central crisis group and set up an alert system within 30 days of notification which will comprise state; district, and local level groups.

Consequently, these provisions did not fully accommodate citizen's empowerment tools. First, the 60-Day prior notice given in the Section 19 of EPA, 1986 gave a polluter enough time to legally get away with the purported environmental crime. Nevertheless, a citizen's sample was not legally admissible in the court of law. Only a Pollution Control Board was a legal institution to submit an environmental sample in a court of law. In the United States, a citizen has a right to submit an environmental sample under an affidavit and hence have that sample allowed in a court of law. This is not the case with India.

\subsection{The Right to Know}

The right to know comes under fundamental right to speech in the Constitution of India as stipulated in Article 19(1) (a) and the fundamental right to liberty and personal liberty as stipulated in Article 21 of the Indian Constitution. In the aspects of Environmental law, this has been recognized by Justice Mathew in 1975 in a ruling on State of Uttar Pradesh v Raj Narain and also by Justice Mukherii in 1989 in Reliance Petrochemical Ltd v Proprietors of Indian Express Newspapers Bombay. However, the right to know has become a costly issue in Indian Environmental Justice movement. For example, to obtain information from a particular polluting unit in question, one has to approach the Pollution Control Board. Being a Government's agency, the PCB is liable to the Indian Evidence Act that prohibits a person from parting with any information passed on to him in his official capacity. Section 123 and 124 of the Act implies that the Court of Law can be denied access to documents if it is the Government's opinion that the documents relate to affairs of the state or country. Similarly, the amendments made to the commission of Inquiry Act (1962) makes it possible 
for the Government to withhold information if it feels that it is in the state or national interest to do so.

\subsection{Public Interest Litigation}

No Post-Stockholm legal gateway in the Indian environmental enforcement history has been as extensively used by the citizens as the Public Interest Litigation (PIL). A PIL is a constitutional right. Article 32 and Article 226 of the constitution empower a citizen to move the Supreme Court and High Courts, respectively, for a direction to the State for restoring a fundamental right. PIL came into existence in the early 1980s when reformist and activist judges such as P.N. Bhagwati and V.R. Krishna lyer started creative interpretations of the law to allow citizens not directly affected by an injustice to file petitions in court on behalf of those less privilege and therefore unable or reluctant to approach the court. This ushered in a new genre of cases known collectively as Public Interest Litigation.

Since 1980s, PILs have progressed further beyond what was originally thought. In Dr. N.S. Subha Rao v the Government of Andhra Pradesh (1988) the High Court of Andhra Pradesh gave people of a particular locality a relief from a polluting factory. In L.K. Koolwal v State of Rajasthan, (1988), the Rajasthan High Court allowed petition of the citizens of Jaipur for the preservation of water sanitation in the city. Also, in Kinkri Devi v State of Himachal Pradesh (1988) the High Court there directed the closure of a mining company to prevent further pollution of the local environment.

M.C. Mehta cases perhaps bear the highest tone of judicial activism never seen before in the legal aspects of environmental enforcement. For example, M.C. Mehta $v$ Union of India and Shri Ram Food and Fertilizer Industries $v$ Union of India (1987) depicts the ethical debate of the environmental protection and the price of development. Another landmark M.C. Mehta case was the petition that moved the Supreme Court for prevention of nuisance caused by the pollution of River Ganga in order to protect the lives of the people who make use of its waters. Moreover, in Indian Concil v Enviro-Legal, the Supreme Court of India entertained a petition of the people living in village due to sludge waste left out by closed-down industries which caused heavy damage to the environment. The Count ordered a remedial action be taken and compensation be given to for the silent tragedies in line with the Mehta's "Absolute Liability Principle"

PILs have been the easiest way of approaching the Higher Courts for environmental justice. Thousands of litigations have been filed at the Supreme Court and this has caused a delay in a speedy justice. In Maharashtra, for example, one PIL case could take an average of six years for completion. Ruling is another problem. 
Lack of cooperation between a State, petitioner, and Judiciary is another obstacle as the Government is often among the accused in these litigations. Lack of access to information on polluter's history is another burden on a PIL petitioner. Another problem is misuse of the right to PIL by people. This so happens because many people are ignorant of the steps and procedures required for a PIL.

It is the latter part of the above factors that compound problems of PlL that has forced the Government of India to come up with new sets of stringent rules required for a PIL. In 1996 the Government announced some steps to curb the profligacy in PILs as they were allegedly choking the system. This introduced bill called for an increase in a mandatory interest-free deposit of Rs. 1,00,000 for every PIL to be placed in the Supreme Court, and a deposit of Rs, 50,000 for PILs to be placed before High Courts. The money was to be refunded if the petitioner won the case and forfeited if the petitioner lost the case. The exception would be in the case of enforcement of the right of the poor.

\section{The Role of Enforcement Agencies: Status and Challenges}

In India, the Central Pollution Control Board was established under the provision of the Water (Prevention and Control of Pollution) Act, 1974. This follows the recommendations of the special committee that was set up in 1962 to draw a draft enactment for the prevention of water pollution. CPCB was a response that was sought to curb the pollution of various water resources in the country that was already affecting the quality of potable water and the overall ability of water to sustain rapid level of pollution by development activities.

As explained earlier, the composition of the Pollution Control Boards was first defined in the Water Act of 1974. The boards are usually composed of a qualified Chairman; a full time secretary; five official members; Three official members each coming from the fields of Agriculture, fishing, and industry or Trade respectively; two persons representing Government corporations; members of the SPCB boards; etc.

$\mathrm{PCBs}$ are given powers to do the following: discretion to give consent to applicants for establishing operational facilities; make, vary, or revoke orders to prevention and control of water pollution; powers of order to construction; modification; alternation; or extension of safe disposal systems; powers to order remedial measures necessary to prevent and control pollution; planning and advisory measures; collection of information and inspection; laying down of standards and participation in investigation and research. 


\subsection{Legal Challenges Facing the PCBs}

Any Environmental legislation is based on resources and tools for enforcement. Any pollution control authority must require instruments for such regulatory approach. These include a variety of economic incentives; fair, efficient, relevant and updated regulation with accompanying environmental standards. and norms; effective guidelines for enforcement and effective public participation. For a long time since 1974, many polluters have disregarded the directions of pollution control boards and violating the conditions of consent with impunity. This is because since from the start, PCBs have not been fully empowered to exercise coercive powers of their own; and most part of this comes form the clash of jurisdiction of powers. The core of contention is the fact that PCBs face hostile legal provision for penal action against polluters.

Overdependence of the legal system is perhaps one of the major problems engulfing enforcement actions by the PCBs. Unlike several other countries such as the US, UK, Canada, and Australia where regulatory agencies have clearly defined mandate to prosecute polluters without approaching the courts of law, in India, PCBs are required to approach the judiciary for this purpose. This often encourage legal wrangling by polluters.

In accordance to the EPA, the PCB must file a case before the lower court for action against a polluting unit and therefore the "onus of proof" is always vested with the PCB. The fact is lower courts are too busy to devote enough time for environment related litigations, unlike in the case of Supreme Court and Green Benches of Higher Courts As a result, thousands of legal cases filed by PCBs against polluters are still pending for many years. Nevertheless, in the number of cases where decisions have been reached, polluters have been given benefit of the doubt because of failure of PCBs to satisfy the courts with the "onus of proof". Polluters also engage in prolonged legal wrangling even after convictions to escape deterrent penalties. They recruit highly paid professional lawyers to plead with their cases whereas the PCBs are disenchanted with the legal procedures. This is why most PCBs would rather go for an arbitrary decision by taking direct action as under Section 33(A) of the Water (Prevention and Control of Pollution) Act, 1974. This sometimes comes with heavy legal consequences against the PCB, as will be seen in the following examples:

For example, in M/S/ Delhi Bottling Co Pvt. Ltd v Central Pollution Control Board (1986), the question was whether the procedure under Section 21 of the Water (Prevention and Control of Pollution) Act, 1974, was necessary to collect legal samples for analyses under section 33 of the Act and whether the sample had been collected according to the procedures required for collection of a legal 
sample as under Section 21 (5) of the Act. The Delhi Court held that Section 21 was not properly followed by the PCB and therefore the sample was not admissible as evidence. Also in Mahabir Coke Industry v Pollution Control Board, the PCB directed the closure of industry as per Section 31(A) of the "Power to Give Directions". It was held by the court that the sample was not taken in accordance to the Act.

Another example of legal wrangling is in Mandhu Distillery Pvt Ltd $\vee$ M.P. Pradhusahn Niwaran Mandal (1995). A question was whether Section 33(A) of the Act which explains a power of a board to direct closure of industry and regulation of electricity was restricted or not. The court ruled that the respondent $(P C B)$ issue fresh show cause notices and take samples for analysis to issue proper directions.

In M/S Suma Traders $v$ Chairman, Karnataka State Pollution Control Board, the case was whether the Chairman of the KSPCB had any competence under the Act to pass any order under Section 31 (A) and Section 15 of the Act. The court held that the Chairman acted in arbitrary manner and that this was a misuse of statutory powers. The PCB's order was suspended by the court and so the Chairman as his personal liability had to pay Rs. 2,500/- to the petitioner.

\section{Can Citizens be Actively Involved?}

It is important to note here that citizens have been explicitly excluded from legal monitoring and enforcement action. Their public participation has been limited to a few areas such as PlLs; public hearings for EIA; and under Citizen's suits. Somehow there is a feeling in from the public viewpoint that many post-Stockholm statutes have connived in letting a polluter use legal loopholes and get away with their environmental crimes. What underlines this opinion is the fact that citizens are not allowed to present legal samples in a court of law.

A development of a citizen's enforcement culture is therefore a very important step. In the face of administrative inefficiencies in environmental investigations and law enforcement, our present environment desperately needs citizen's help. It is much cheaper and more efficient to develop citizen's involvement in a fight against environmental crimes. Certainly, any citizen would know what is going in their locality. They can easily identify pollution situation and hence identify a pollution source. Citizens can work with the PCBs in obtaining documents on the suspect industries under the right of information provision; they $c$ an also check whether something is being done about an environmental problem in their locality. Since we have recognized environmental laboratories across the country, citizens 
can approach local or nearby environmental laboratories for identification of a pollutant, its sampling and subsequent analysis. Contacts to various regulatory agencies such as the PCB can be established in case of a pollution problem. Eventually, a citizen can proceed with legal action by exploring various judicial gateways.

\section{Conclusion}

It is clear from the above accounts of various legal environmental aspects that both pre-Stockholm and Post-Stockholm provisions are as much important when mutually taken into account as they would be if taken separately. There is a need to improve penalties in common law provisions so that they cam match up. with the impact of environmental crimes. Bar of jurisdiction as laid down in the Water and Air Acts should not be allowed to interfere with the Common law jurisdiction. Justice is a fundamental right of every citizen and so it is important that citizens should be empowered to present legal sample in the court of law. The right to know is a basic pillar for environmental justice and denying a citizen that right is equal to denying the citizen the right to fight pollution crimes. Despite their success, Plls still do not entirely gives a citizen the right of claims or compensation. Moreover, in India, many environmental lawyers are classified under the 'pro bono".

The most important part in the post-Stockholm statutes is the ability of citizens to pursue environmental justice in various legal gateways one of which involving the inclusion of the Government Agency in fighting the environmental crime. Pollution Control Boards have been given clear and visible powers to make sure that the industrial facilities comply with the laws laid down and what enforcement is carried out at maximum efficiency. But, clearly, the only way to carry out environmental enforcements is the active inclusion of ordinary citizens in ensuring that the environmental laws of the land are not flouted.

(Acknowledgement: The Authors wish to cicknowledge the great support and guidance from Prof. M.K. Ramesh, National Law School of India University (NLSIU)

\section{Selected References}

1. Aganwal, M.K.; (1987); Judicial Approach to Environmental Law; Environment Management in India (Nulme l); Sapru and Khooshoo; Ashish Publishing. House; pp 103.

2. Babu, K.L.; (2002); Inspections; Training Program on Environmental Enforcement for Officials of the Pollution Control Boards

3. CEERA Research Team; Major Environmental Laws in India (Documents Vol l) 
4. Down To Earth; (1992); A Tool to Aid Democracy Lies Rusting; Down To Earth; Society for Science and Environmental Communications;. Vol 1; No. 6; August 15, 1992.

5. Down To Earth; (1992); Making the Right Choice; Down To Earth; Society for Science and Environmental Communications; Vol 1; No. 12; November 15, 1992

6. Down To Earth; (1996); Courting Justice; Down To Earth; Society for Science and Environmental Communications; Vol 5; No.1; May 31, 1996

7. Down To Earth; (1997); Pilfering Citizen's Rights; Down To Earth; Society for Science and Environmental Communications; Vol 5; No.20; May 15, 1997

8. Justice N Venkatawala; (2000); Affected People Can Even Approach the Criminal Court; Down To Earth; Society for Science and Environmental Communications; Vol 8; No. 24; May 15,2000

9. K. Yeshodhara; Environment Protection Constitutional and Legislative Provision; Environmental and People; Vol 5; No.9.

10. Kanwaljit Kaur; (2000); Law and Disorder; Down To Earth; Sociefy for Science and Environmental. Communications; Vol 6; No. 23; December 15, 2000.

11. Karkara, G.S. (2000); Environmental Law; Central Law Publications

12. Leelakrishnan P.; (1999); Environmental Law in India; Buttenworths Publications

13. Leelakrishnan, P; (1992); Public Participation in Environmental Decision Making; Law and Environment; Leelakrishnan; Eastern Book Publications Company.

14. Low N.; Gleeson B.; (2000); Ecosocialization and Environmental Change; Papers for the Conference of the International Critical Geography Group; University of Taegu

15. M. Sridhar Archarhulu; Hospital Waster Management and Principles of Liability Efficient Laws Minus Enforcement; Environmental and People Vol. 5; No. 9

16. Member Secretary of Andhra Pradesh Pollution Control Board; (2000); Defining Our Todays; Down To Earth; Society for Science and Environmental Communications; Vol 8 ; No. 17; January 31,2000

17. N.C. Saxena; (2000); Hazardous Waste Rio Proposes, Morket Disposes; The Hindu Survey on Environment 2000; pp 53, pp 55.

18. P.N. Bhagwati; P. M. Bhargava, Rajeev Dhawa; Rajiv Uora; (1997); Order, Order; Down To Earth; Society for Science and Environmental Communications; Vol 5; No.24; May 15, 1997

19. Parikh, P; Wardzinski, K.; (2002); Comparatice Perspective: Environmental Enforcement in the United States ; Training Program on Environmental Enforcement for Officials of the Pollution Control Boards.

20. Prokash, S.; (1997); We the People; Down To Earth; Society for Science and Environmental Communications; Vol 2; No.3;

21. Rajat Banerjee, Madhumita Dutta; (1996); Thou Shalt Inform; Down To Earth; Society for Science and Environmental Communications; Vol 4; No. 19; February, 1996

22. Rajat Baneriee, Max Martin; (1997); Courting Green; Down To Earth; Society for Science and Environmental Communications; Vol 5; No 24.

23. Rosencraz, A; S. Divan; Noble, M.L.; (1995); Judicial Remedies and Procedures; Environmental Law and Policy Cases Materials and Statutes; $2^{\text {nd }}$ Edit.; $p 77$

24. Sagar Dhera; Thoughts on Stakeholders' Environmental Strategy; Environmental and People; Vol 5; No 9. 
25. Sazalla Jeevananda Reddy; Industrial Pollution in Andhra Pradesh A Perspective; Environment and People; Vol. 9; No. 1.

26. Shanthakumar, S.; (2001); Remedies for Environmental Pollution; Environmental Law In Introduction; Surya Publications; pp 145.

27. Sharma, B.R.; (1987;) Environment Management in India An Overview; Environment Management in India Nolume 1) Sapru and Khooshoo; Ashish Publishing House; pp 158 167.

28. Sheth, P.; (1997); Environmentalism Politics, Ecology, Development; Rawat Publications.

29. Shiyam Divani; (2002); A Mistake of Judgement; Down To Earth; Society for Science and Environmental Communications; Vol 10; No. 23; April 20, 2002

30. Singh, Chatrapathy; (1992); Legal Policy for Environimental Protection; Law and Enforcement; Leelakrishnan; Eastem Book Publications Company;

31. Singh, P.D.; (1987); land Us Monitoring for Effective Management of Environment; Environment Management in India (Vulme l); Sapru and Khooshoo; Ashishi Publishing House; pp 44.

32. Sujit Chakraborty; (1995); Green Justice Up in Smoke; Down To Earth; Society for Science and Environmental Communications; Vol 4 ; No. 9; September 30, 1995

33. Thakur, K.; (1997); Environmental Protection Law and Policy in India; Deep and Deep Publications; pp 184.

34. . Trivedy, R.K.; (1996) A Handbook of Environmental Lows; Acts, Rules, Guidelines, Compliances, and Standards; Enviromedia Publications.

35. V. Vidyanath; Environment and Constitutional Protection; Environmental and People; Vol 6; No. 10.

36. Wardszinski, P.; Sengupta, B.; (2002); Identifying Enforcement Objectives and Choosing Among Enforcement Options; Training Program on Environmental Enforcement for Officials of the - Pollution Control Boards. 